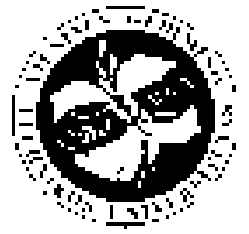

\title{
SUSIJUNGUSIŲ ORGANIZACIJŲ KULTŪRŲ POVEIKIS İMONĖS SĖKMEI
}

\author{
Vida Vaitkūnaitè \\ Vilniaus Gedimino technikos universitetas, Saulètekio al. 11, LT-10223 Vilnius-40, Lietuva \\ El.paštas vvaitkun@yahoo.com
}

Iteikta 2005-10-14; priimta 2005-11-29

\begin{abstract}
Santrauka. Imonių nesėkmès privertė mokslininkus atkreipti dèmesi i nematerialius organizacijos dalykus. Pastebėta, kad sėkmę ar nesėkmes gali lemti organizacijos kultūra. Daugiausia tyrejjų ši poveikį analizavo nesusijungusiose organizacijose. Tačiau susijungiančiu įmonių vis daugejja, o tyrimų yra mažai ir jie nèra išsamūs. Šiame straipsnyje aptariama kultūros samprata, poveikis sėkmei, atskleidžiamos susijungusių įmonių kultūrų analizės problemos ir pateikiami kultūros poveikio sèkmei tyrimo metodikos metmenys: siūloma derinti kiekybinius ir kokybinius tyrimo metodus, tyrimą suskirstyti $\mathfrak{i}$ tris periodus ir įmones analizuoti kaip atskirus vienetus, o ne kaip vientisa jungini.
\end{abstract}

Pagrindiniai žodžiai: organizacijos kultūra, susijungusios įmonès, įmonių sėkmè, tyrimo metodika

\section{THE IMPACT OF MERGED ORGANIZTIONS CULTURE ON ENTERPRISE SUCCESS}

\author{
Vida Vaitkūnaitè \\ Vilnius Gediminas Technical University, Saulètekio al. 11, LT-10223 Vilnius-40, Lithuania \\ E-mail:vvaitkun@yahoo.com
}

Received 14 October 2005; accepted 29 November 2005

\begin{abstract}
Summary. Failures of enterprises forced scientists to pay attention to intangible side of organization. They note that organizational culture can cause success or failure. Most scientists analyzed this influence in non-merged organizations. However, enterprises merge more often, but there are few investigations and they are not comprehensive. In this article the author discusses the concept of organizational culture, its impact on success, discloses the problems of culture analysis of merged companies and proposes the outline of research methodology of culture impact on success. It is proposed to combine quantitative and qualitative research methods, to distribute research into three periods and to separate companies into separate unit, not analyzing them as a single one.
\end{abstract}

Keywords: organizational culture, merged companies, enterprises success, research methodology

\section{Ivadas}

Šiuolaikinès rinkos sąlygos - aštrèjanti konkurencija, didèjantys klientų poreikiai, globalizacija ir pan. - skatina imones kooperuotis. Išskiriami tokie kooperacijos būdai: isigijimas - viena įmonė nuperka kitą imonę; susijungimas - dvi ar daugiau imonių susilieja. Abu šie atvejai straipsnyje ivvardijami imonių susijungimu. Susijungimą skatina i̇vairios priežastys: visų pirma, trumpalaikis tiks- las - pelnas, gaunamas parduodant imonès turtą [1]; antra - siekis sukurti sinergiją finansu srityje, padidinti rinkos dali, sumažinti riziką ir pan. [1, 2]. Tačiau praktika parode, kad daugelis tokių susijungusių imonių žlunga [1, 3-5] arba imonių veiklos rezultatai pablogeja [1] vien todèl, kad rūpinamasi materialiais dalykais, o nematerialioji organizacijos dalis, literatūroje ịvardijama kaip organizacijos kultūra, užmirštama [1, 3]. Ji susiformuoja kiekvie- 
noje organizacijoje darbuotojams bendraujant tarpusavyje ir su išorine aplinka (klientais, tiekejais, akcininkais, visuomene) [6]. Tyrèjai sutaria, kad organizacijos kultūra daro itaką imonès sèkmei, tačiau kyla klausimas - koks kultūros poveikis sèkmei, kai įmonès susijungia. Mokslinè problema ta, kad organizacijos kultūros poveikis susijungusių imonių sėkmei mažai nagrinètas ir nėra aiškios metodikos, kaip tirti susijungusių imonių kultūras, norint ši poveiki ivertinti. Tai lèmè šio straipsnio tikslą - pateikti susijungusių įmonių kultūros tyrimo metodikos metmenis. Darbe panaudota sisteminè mokslinès literatūros analizè, apibendrinimo ir loginès analizès metodai.

\section{Organizacijos kultūra ir jos pokyčiai}

Norint ivvertinti kultūros poveiki, ją reikia pažinti. Organizacijos kultūros sąvoką imta vartoti pasikeitus požiūriui i organizaciją. Anksčiau organizacija buvo suprantama kaip negyvas, mechaninis objektas, kuriame darbuotojai tèra organizacijos-mašinos dalis [7], o dabar vis labiau akcentuojamas organizacijos kaip gyvo socialinio organizmo aspektas. Taigi darbuotojus pradèta vertinti kaip organizacijos turta. Jiems sąveikaujant, kuriasi tam tikra bendravimo sistema, tam tikras vadovavimo stilius, atsiranda taisyklių, papročių, vertybių, kitaip tariant, susiformuoja organizacijos kultūra.

Kiekviena organizacija turi unikalią kultūrą [8]. Ji organizacijai yra tas pat, kas asmenybė žmogui $[1,9]$. Kultūrą taip pat galima îvardyti socialiniu organizacijos veidu, veikimo būdu [10]. Ji suvienija organizacijos narius bendram darbui $[8,9]$. Kultūrą nusako ir ìvairūs organizacijos simboliai, istorijos, tradicijos, taisyklès, mitai ir pan. [1113]. Apibrèžimų daug, tačiau dažniausiai cituojamos Schein [6] mintys apie organizacijos kultūrą - tai pagrindinès organizacijos narių nuostatos, kurios susiformuoja savaime, sprendžiant prisitaikymo prie išorinès aplinkos ir vidinès integracijos problemas. Niekas darbuotojų neverčia vadovautis šiomis nuostatomis. Jos formuojasi ne tik susidūrus su problemomis, bet ir kiekvieną dieną. Todèl kultūros apibrèžime nereikètų akcentuoti problemų. Schein [6] teigia, kad kultūrą taip pat sudaro fizinė aplinka, vadinama artefaktais (t. y. tai, ką galima matyti, girdeti, jausti; pavyzdžiui, kalba, aprangos, rašymo stiliai, ritualai, ceremonijos, mitai, architektūra, meno kūriniai ir kt.) bei vertybès (jos parodo, kas organizacijos nariams yra priimtina, o kas ne, ką galima daryti, o ko ne ir pan.).

Iš kultūros apibrèžimų matome, kad ji glaudžiai susijusi su organizacija. Todèl ją detaliau ir panagrinèkime. Poole ir Van de Ven [14] organizacijas ivvardija stabilumo ir pokyčių mišiniu. Autoriai pabrěžia, kad organizacijos yra tarsi stabilios. Tačiau, idèmiau pažvelgus, pasirodo, kad jos nuolat kinta. Denison [15] taip pat teigia, kad organizacija kaip sistema yra inertiška ir tik tol būna stabili, kol vienu metu dèl tam tikrų aplinkybių nepasikeičia simbolinių reikšmių ir adaptacijos sistema, kitaip tariant, kol neįvyksta ryš- kus pokytis, dèl kurio darbuotojai įvairius dalykus pradeda vertinti kitaip nei anksčiau ir turi prie to prisitaikyti. Vykstant pokyčiams organizacijoje kinta ir kultūra [15].

Imonių susijungimą taip pat galima îvardyti pokyčiu. Imonèms jungiantis, darbuotojai susiduria su kitokia mąstysena, elgsena, vadovavimo būdu, sprendimu prièmimo specifika ir tradicijomis. Jie turi prisitaikyti prie naujų dalykų. Taigi senoji kultūra pradeda keistis savaime arba vadovai imasi iniciatyvos ją keisti. Kultūros keitimas susijęs su pagrindinių nuostatų keitimu [11], kurios, anot Schein [6], issišaknijusios darbuotojų sąmonèje, jų sunku atsisakyti, ir darbuotojai tam priešinasi. Vadinasi, kultūrų susidūrimas ,pakoreguoja“ imonių veiklos rezultatus, nes sėkmè priklauso nuo žmonių integracijos [3]. Taigi svarbu, kad susijungusiose imonèse nesusidarytų ,negatyvi žmonių kombinacija“" [3], ivvardijama kultūrų nesuderinamumu [16].

Kaip matome, kultūra formuojasi tiek pokyčiu metu (tuomet susiduriama su problemomis), tiek evoliucionuoja kasdien. Taigi apibendrinus įvairių mokslininkų mintis apie organizacijos kultūrą jos apibrèžimą galima patikslinti. Organizacijos kultūra - tai įmonei (jos darbuotojams) būdinga elgsena, mąstysena ir išorinis pavidalas (pavyzdžiui, organizacijos struktūra, simboliai ir pan.), susiformavę darbuotojams bendraujant tarpusavyje ir su išorine aplinka bei išreikšti tik tos įmonès darbuotojams būdingomis nuostatomis, îsitikinimais ir vertybèmis.

\section{Ryšys tarp organizacijos kultūros ir ịmonès sẻkmès}

Kiekviena organizacija siekia sėkmingos veiklos. Todèl įmonių vadovus ir tyrèjus domina keli svarbūs klausimai - ar egzistuoja ryšys tarp organizacijos kultūros ir įmonès sèkmès ir kaip ji rasti. Literatūroje vartojama ne tik sèkmès, bet ir organizacijos veiklos sąvoka. Teigiama, kad imonès veiklos rezultatai priklauso nuo organizacijos kultūros. Veikla gali būti tiek sėkminga, tiek nesėkminga. Vienoki kultūros bruožai lemia sėkmę, kitokie - nesėkmes. Literatūroje pateikiamus sėkmès apibrèžimus galima suklasifikuoti pagal sèkmès traktavimą: 1) finansiniais rodikliais (rinkos dalies, pelno, pajamų, pardavimo apimčių, akcijų kainos ir kt.) išmatuojama sèkmè [11, 15, 17-21] ir 2) ne finansiniais rodikliais išreikšta sėkmè (darbuotojų bei klientų pasitenkinimas [10], imonès stabilumas [22], organizacijos efektyvumas $[8,11,17,23-25]$, imonès konkurencingumas [26], imonès augimas ir plètra [27], imonès stiprumas $[8,19,28])$.

Trumpai tariant, organizacijos kultūra gali sutelkti darbuotojus i stiprią komanda. Dèl to auga darbo efektyvumas, taigi gerèja finansiniai rezultatai, didejja konkurencingumas. Vadinasi, immonė veikia sėkmingai. Tačiau kultūros poveikis veiklos rezultatams gali būti ir neigiamas [19]. Problema, ieškant kultūros poveikio sėkmei, yra ta, kad mokslininkai nenaudoja vienodų sèkmès matavimo rodiklių - vieni autoriai naudoja finansinius, kiti ne finansinius rodiklius, o ir šie skiriasi. Todèl dažnai skirtingų moks- 
lininkų gautų rezultatų palyginti neįmanoma. Kadangi daugeli finansinių rodiklių veikia ne finansiniai rodikliai, abi rodiklių grupes vertètų analizuoti kartu.

Vieni mokslininkai kultūros poveiki imonès veiklai pagrindžia tik teoriniais samprotavimais, kiti [15, 20, 21]empiriniais tyrimais.

Tyrèjai i̇monès sèkmę taip pat sieja su:

1) kultūros stiprumu $[20,24,29]$. Kultūros stiprumas tai organizacijos narių sutarimo ir identifikacijos su imonejje dominuojančiomis normomis laipsnis [29];

2) kultūros tipu [15, 16, 27, 30].

Daugelis autorių kalba apie ryši tarp organizacijos kultūros ir įmonès sèkmès, tačiau yra mokslininkų, abejojančių šio ryšio egzistavimu. Pavyzdžiui, Harris ir Metallinos [21] nesutinka, kad kultūra gali pagerinti finansinę imonès veiklą. Empiriniai tyrimai, kaip jau buvo minèta, patvirtina, kad ryšys egzistuoja. Daugelis tyrejuu šias išvadas pateikè išanalizavę nesusijungusias organizacijas. Jų išvadas ir tyrimo metodiką galima taikyti tiriant ir susijungusias imones. Tačiau tikètina, kad tiek rezultatai, tiek metodika jiems gauti bus skirtinga jau vien todèl, kad susijungimas yra pokytis, kurio metu susiduria dvi skirtingos žmonių komandos.

\section{Susijungusių organizacijų kultūros analizè}

Lietuvos mokslininkai dar netyrè susijungusių imonių kultūros ir jos poveikio i̇monès sėkmei. Todèl tenka naudotis kitų šalių mokslininkų patirtimi. Kai kurie autoriai $[1,3,9,10,16]$, nagrinejjantys imonių susijungimus, bando atsakyti i klausimą - kaip išvengti nesèkmių. Jie pabrèžia, kaip svarbu pasiruošti susijungimui, ir kalba apie galimą kultūrų nesuderinamumą. Tačiau šie autoriai išskiria mažai kultūros aspektų, turinčių ittakos įmonès sèkmei. Pavyzdžiui, Horwitz ir kt. [18], tirdami susijungimo periodą (autoriai taiko kokybinius tyrimo metodus), nustato, kad veiklos rezultatai priklauso nuo žmogiškujų išteklių valdymo. Tačiau tyrejjai nedetalizuoja kultūros bei veiklos rodiklių. Vadinasi, susijungimas nèra įvertinamas išsamiai, nes, norint įmones palyginti, reikia naudoti tuos pačius kultūros aspektus ir veiklos rodiklius. Nahavandi ir Malekzadeh [1] taip pat analizuoja susijungusias organizacijas, bet neišryškina sėkmę veikiančių kultūros aspektų. Jie mano, kad sėkmè priklauso nuo abieju i̇monių pasiruošimo. Tačiau tam būtina žinoti, kokie kultūros aspektai gali trukdyti, kokie padèti. Autoriaus padarytų išvadų negalima pritaikyti daugeliui kitų imonių susijungimo atvejų, nes buvo ištirti tik keturi atvejai. Be to, neparodytas ryšys tarp kultūros ir įmonès sèkmès, o ir sèkmè apibrèžta miglotai sėkme autorius i̇vardija tai, kad i̇monès nežlugo, nors kai kurių susijungusių imonių rezultatai po netgi pablogèjo.

Kiti mokslininkai $[15,31]$ išskiria kultūros aspektus (dèmesi klientui, organizacijos mokymuisi, keitimuisi, tobulejimui, komandiniam darbui ir igaliojimui, strateginei krypčiai ir ketinimams, tikslams, vizijai, koordinacijai ir integracijai, sutarimui ir pagrindinėms vertybėms) ir veiklos rodiklius (produkto/paslaugos inovacijas, rinkos dali, pardavimo apimčių augimą, investicijų, turto ir pardavimų pelninguma, kokybę ir darbuotojų pasitenkinima). Tačiau ryšius tarp jų analizuoja ne susijungusiose organizacijose. Vis dèlto įmonių susijungimas yra didžiulis pokytis, todèl ivvairūs kultūros aspektai veiklos rezultatus gali veikti visai kitaip nei nesusijungusiose organizacijose. Jose ryši tarp kultūros ir veiklos rezultatų patvirtina tiek kiekybiniai, tiek kokybiniai tyrimai [31, 32]. Susijungusių organizacijų kultūros poveikis sèkmei dar nèra išsamiai išanalizuotas.

Denison [15] teigia, kad jo modelis, leidžiantis įvertinti kultūros poveiki veiklos rezultatams, tinka ir kultūros pokyčiams analizuoti. Kadangi įmonių susijungimas lemia imonių kultūros pokyčius, vadinasi, modelis galètų būti tinkamas šiam atvejui analizuoti. Modelio esmè ta, kad organizacija gali sužinoti savo kultūros silpnąsias ir stipriąsias vietas, pamatyti, kaip tai veikia veiklos rezultatus, ir palyginti savo organizaciją su kitomis imonèmis. Taigi imonès, norinčios susijungti, pamatytų, ar jos rūpinasi tais pačiais, ar skirtingais dalykais. Vadinasi, būtų îvertinamas galimas kultūrų nesuderinamumas. Tačiau ịmonès gali rūpintis panašiais dalykais, bet susijungusios patirti nesèkmę. Jos gali skirti dèmesi skirtingiems dalykams, o susijungusios veikti gana sėkmingai. Pavyzdžiui, viena imonè daugiau dèmesio skiria darbuotojams, kita - klientams. Susijungus ir suderinus šiuos dalykus, galima pasiekti neblogų rezultatų. Be to, jeigu susijungusios imonès mažai bendrauja, skirtumai taip pat neturètų trukdyti [1]. Taigi susijungus kultūros aspektai gali veikti skirtingai, nei iprasta. Todèl reikia nustatyti jų poveiki. Minètuoju Denison [15] modeliu organizacijas imanoma tirti bet kada. Autorius akcentuoja ne tik kiekybinès, bet ir kokybinès analizės svarba, tačiau susijungimų neanalizuoja ir jungimosi metu galèjusių išryškèti kultūros aspektų neišskiria. Taigi analizuodami susijungusias imones galètume panaudoti tik šio autoriaus išskirtus kultūros aspektus bei veiklos rodiklius.

Schein [6] taip pat teigia, kad kultūra daro ịtaką imonès veiklai, tačiau nenurodo su sėkme susijusių kultūros aspektų. Susijungimų autorius neanalizuoja, bet pasiūlo vadinamaji klinikini tyrimo būdą. Jis pagrịstas reiškinio tikrovès analize - tyrèjas, norėdamas nustatyti darbuotojams būdingas vertybes ir nuostatas, ima iš jų interviu, dalyvauja įmonès veikloje ir stebi organizacijos narių veiksmus. Toks tyrimas teikia vertingu atsakymų apie susijungimo periodu išryškejjusius kultūros aspektus, tačiau neparodo, kaip jie susiję su veiklos rezultatais. Be to, kokybiniai tyrimo metodai dažniausiai atskleidžia specifinius susijungimo aspektus [10], kurie būdingi tik paskiroms organizacijoms, bet nebūdingi kitoms įmonėms. Todèl reikètų taikyti kiekybinius tyrimo metodus, kurie padètų nustatyti ir kultūros aspektų poveiki veiklos rezultatams, ir bendrus susijungusių imonių bruožus. Kadangi vien kiekybinis tyrimas susijungimo metu išryškèjusių kultūros aspektų taip pat 
visiškai neatskleis [10], kokybinius ir kiekybinius tyrimo metodus verta derinti. Taigi kiekybiniai tyrimai atskleis susijungimo dèsningumus, bendrus susijungusių įmonių bruožus, o kokybiniai metodai suteiks papildomos informacijos.

Kaip pažymejjome, vieni mokslininkai analizuoja nesusijungusių imonių kultūrų poveiki sėkmei; kiti autoriai tik aprašo, kaip tirti susijungusių imonių kultūras, bet aprašyta kultūros tyrimo metodika nèra išsami; treti tyrëjai išskiria mažai kultūros aspektų, kurie gali daryti poveiki susijungusių imonių sèkmei.

Daugelis susijungimus nagrinejjusių mokslininkų tiria vieną laikotarpi - imonių jungimosi periodą. Cartwright ir Cooper $[2,3,9,16]$ mano, kad ji verta suskirstyti detaliau, t. y. susijungusių imonių kultūras analizuoti: 1) pokyčio pradžioje, 2) tuomet, kai pokytis vyksta, ir pagaliau 3) kai integracija (susijungimas) įvykusi. Toks tyrimas padètų pamatyti kultūros dinamika, rasti bendrų įmonių jungimosi bruožų ir specifinių problemų [2]. Idèja suskirstyti įmonių jungimosi laikotarpi periodais yra nebloga. Tačiau toki tyrimą reikia atlikti i̇monèms jungiantis. Jeigu jis bus atliekamas praejus nemažam laiko tarpui po susijungimo, darbuotojai, atsakinėdami i tyrèjo klausimus, gali susipainioti, kas vyko pokyčio pradžioje, kas pabaigoje.

Pokyti svarbu ne tik analizuoti, bet ir ivertinti. Norint ivvertinti pokyti, ji reikia palyginti su statiška būsena [14]. Taigi svarbu atsižvelgti i laika. Denison ir Mishra [32] taip pat akcentuoja laiko svarbą. Jie kultūros poveiki veiklai tyrè skirtingais periodais, tačiau ne susijungusiose įmonèse. Lyginant skirtingu periodų kultūros aspektus ir veiklos rezultatus galima nustatyti, ar tarp jų egzistuoja ryšys ir koks to ryšio stiprumas.

Anot Poole ir Van de Ven [14] norint ivvertinti pokyti (pavyzdžiui, susijungima) pakaktų palyginti dviejų periodų (pavyzdžiui, prieš susijungimą ir jo metu) kultūrų aspektus ir veiklos rezultatus. Tačiau siekiant pokyti ivertinti tiksliau, vertètų išskirti ir daugiau periodų. Kiti autoriai [2, 32], siekdami įvertinti kultūros aspektų poveiki veiklos rezultatams, taip pat akcentuoja, kaip svarbu palyginti kelis laikotarpius, t. y. kuo daugiau duomenų apie kultūros aspektus ir veiklos rezultatus turèsime, tuo tiksliau ivertinsime ryši tarp jų. Galima lyginti tos pačios organizacijos duomenis skirtingais periodais ir/arba daugelio organizaciju duomenis.
Literatūros analizė parodė, kad tiriant susijungusias įmones tyrimo periodai nèra išskiriami. Taigi nelyginama, kaip pasikeitė kultūros aspektai ir jų poveikis sėkmei. Dažniausiai analizuojamas tik vienas, retais atvejais du periodai. Tačiau organizacijas tiriantys autoriai duomenis apie jas renka ịvairiais laikotarpiais. Todèl ir susijungusioms įmonèms laiko matas turètų būti svarbus veiksnys, kuris padètų ivertinti organizacijų (susijungimo) pokyčius, t. y. kaip organizacijų kultūrų, finansiniai ar kiti aspektai pakito. Taigi šiame straipsnyje siūloma, tiriant susijungusias įmones, išskirti šiuos periodus - prieš susijungima, jo metu ir po jo. Susijungimo periodo, kaip siūlo Cartwright ir Cooper [2, $3,9,16]$, smulkinti nereikètu, nes darbuotojai periodus supainiotų dèl jų gausos ir būtų gana sudètinga gauti tikslius atsakymus apie praeities faktus (pastaba: darbuotojai dažniausiai apklausiami tada, kai įmonės jau būna susijungusios, todèl jų klausiama apie praeities faktus). Palyginę ivvairius organizacijų kultūrų aspektus ir finansinius rezultatus minetais periodais, rasime susijungimo (integracijos/ pokyčio) metu išryškejjusius kultūros aspektus, nustatysime jų poveiki sėkmei ir ryšio tarp kultūros aspektų ir veiklos rezultatų stiprumą. Kadangi periodai aiškiai apibrèžiami, darbuotojai neturètu susipainioti, kas ir kaip vyko vienu ar kitu periodu. Grafiškai periodai vaizduojami 1 pav.

Jungimosi periodas tyrèjui yra svarbiausias. Todèl, kaip jau buvo minèta, greta kiekybinio tyrimo, ivertinančio ryši tarp kultūros aspektų ir veiklos rezultatų, verta taikyti kokybini tyrimo būdą, detaliau panagrinèti susijungimo periodą ir palyginti vienos įmonės atsakymus su kitų imonių atsakymais. Tai leis rasti bendrus susijungusiu imonių aspektus. Tuomet bus galima teikti rekomendacijas ateityje susijungti ketinančioms organizacijoms.

Tyrimo suskirstymas periodais naudingas ne tik analizuojant organizacijos kultūros aspektus. Jis gali būti naudingas tiriant ịvairius susijungusių imonių aspektus. Pavyzdžiui, šiuos periodus galima išskirti tiriant imonių finansinès būklès pokyčius. Matysime, ar susijungusios įmonès sukūrè finansų sinergija, ar ne. Taigi pasiūlymas suskirstyti susijungusių įmonių tyrimą periodais gali būti naudingas ne tik vadybos, bet ir ekonomikos krypties tyrejjams. Be to, tyrimo suskirstymas periodais yra naudingas tiriant ivvairius organizacijos pokyčius. Ivertinę organizacijos situaciją prieš pokyti, pokyčio metu ir po jo, pamatysime,

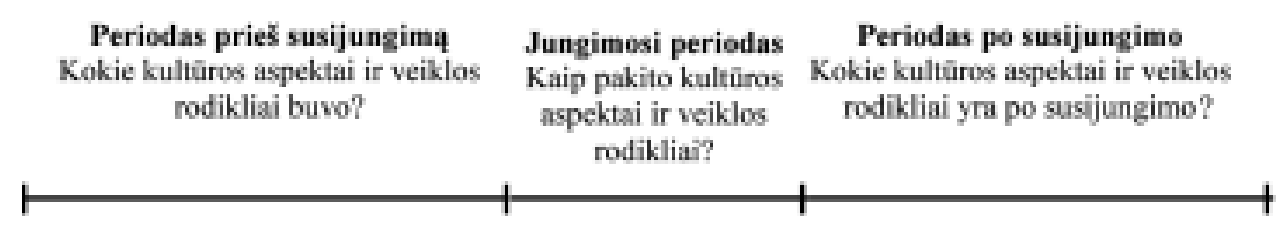

1 pav. Susijungusių imonių tyrimo periodai

Fig 1. Reasearch periods of merged enterprises 
kokios problemos būdingos pokyčio periodu, kokie veiksniai lemė pokyčio sèkmę ar nesėkmes.

Tyrèjas ne visuomet turi galimybę stebèti imonių susijungima, todèl, kaip jau buvo minèta, dažnai tenka analizuoti praeities faktus. Tiriant susijungusias imones, kyla ir laiko problema - kada (kuriuo momentu) imonès yra iki galo susijungusios. Ivairioms įmonèms šis periodas gali būti skirtingas. Tyrèjai nenurodo jo trukmès, todèl šis klausimas gali būti ateities tyrimų objektas.

\section{Organizacijų atskyrimas tyrime}

Analizuodami organizacijas kai kurie tyrèjai $[15,18$, 21] išskiria hierarchinius lygius. Tyrimai rodo, kad skirtingų hierarchinių lygių darbuotojų nuomonès ịvairiais klausimais dažniausiai nesutampa. Denison [15] tyrimas parodè, kad darbuotojų, priklausančių skirtingiems skyriams, požiūriai i kultūros aspektus taip pat gali skirtis. Nahavandi ir Malekzadeh [1], stebėdami susijungusias įmones, atkreipia dèmesi $i$ tai, kad net praejus tam tikram laiko tarpui po susijungimo imonès gali išlikti skirtingos arba tik nedaug supanašèti.

Taigi susijungusių i̇monių narių nuomonès apie kultūros aspektus gali nesutapti. Todèl tokias organizacijas vertètų analizuoti atskirai. Jeigu nèra galimybès stebėti susijungimą ir analizuojami praeities faktai, tai susijungusių ¿monių darbuotojai dažniausiai apklausiami kaip vienai organizacijai priklausantys nariai, o ne kaip atskirų imonių darbuotojai. Kitaip sakant, mokslininkai, analizuojantys senokai susijungusias organizacijas, jas traktuoja kaip vientisa jungini, o ne kaip atskirus vienetus. Jeigu darbuotojai pradejo dirbti kartu (t. y. nebe atskirose imonèse), veiklos rezultatų atskirti net neimanoma, galima tik prognozuoti, kokie jie galèjo būti, jeigu įmonès nebūtų susijungusios. Tačiau, tiriant kultūra, susijungusių i̇monių darbuotojus visada imanoma apklausti kaip atskiroms imonėms priklausiusius narius. Todèl tiriant susijungusias organizacijas jas verta traktuoti kaip atskirus vienetus, o ne kaip vieną organizacija.

Organizacijos suskirstymas ị dalis - tai subkultūrų eg-

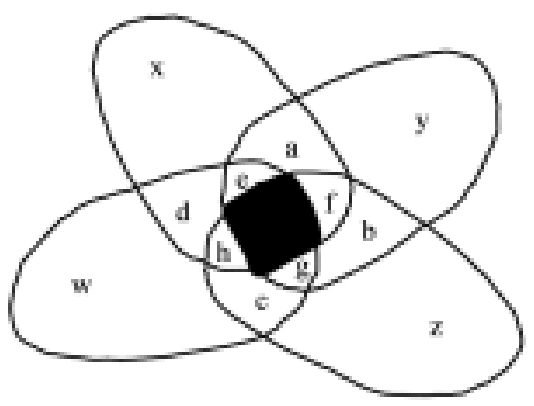

A zistavimo organizacijoje pagrindimas. Net ir tuo atveju, kai darbuotojai pradejo dirbti ,po vienu stogu“, organizacijoje išryškès skirtingos komandos, skirtingos kultūros, ypač tada, kai įmonès dar ne iki galo prisitaikè viena prie kitos. Todèl gali atrodyti, kad naujoje imoneje egzistuoja viena kultūra, o iš tikrujuc susijungusių imonių darbuotojai vis dar nesijaučia priklausą naujam junginiui ir yra tarsi susikirstę $i$ atskiras grupes. Taigi organizacijoje egzistuoja skirtingos subkultūros.

Bjerke ir Elgar [33] teigia, kad subkultūros egzistuoja kiekvienoje kultūroje (taip pat ir organizacijos kultūroje). Kiti autoriai [6, 34-37] taip pat pritaria, kad organizacijose egzistuoja subkultūros. Toks skirstymas kyla iš sistemu teorijos idejos [36]. Viena vertus, organizacijai augant (idarbinant naujus darbuotojus, kuriant naujus skyrius, filialus ir pan.) atsiranda subkultūros, tačiau jos yra panašios i pirminę organizacijos kultūrą [36], nes formuojasi jos veikiamos. Antra vertus, laikui bėgant subkultūros nutolsta nuo pirminès kultūros, suformuoja tik joms būdingus bruožus ir netgi gali nesutarti viena su kita [36, 37].

Organizacijos kultūros ir subkultūrų sąveiką perteikia Bjerke ir Elgar [33] siūlomas kultūros vaizdas (žr. 2 pav.).

Atskirų subkultūrų vertybes, isitikinimus, nuostatas ir pan. vaizduoja $w-z$ plotai; $a-h$ plotai rodo tai, kas yra bendra tarpusavyje bendraujančioms subkultūroms. Jos, jų vertybès, įsitikinimai ir pan. sudaro organizacijos kultūrą. Tačiau organizacijos kultūros šerdis yra tai, kas bendra visiems organizacijos nariams. Ją vaizduoja tamsintas plotas. Jeigu organizacijos nariai turi mažai bendrumų ir jos padaliniai yra autonomiški, tamsintas plotas bus mažas (žr. 2 pav. B). Kuo mažesnis šis plotas, tuo silpnesnè organizacija.

Sustūmę 2 pav. A ir B piešinius, galime pamatyti susijungusių organizacijų kultūrų ir subkultūrų vaizdą (žr. 3 pav.). Jeigu organizacijos turès mažai bendrų dalyku, t. y. labai skirsis, jų veiklos rezultatai gali pablogèti [3].

Paveiksle pateikiamas tik sąlyginis vaizdas. Jis gali skirtis atsižvelgiant i jungimosi situacija. Ką tik susijungusios organizacijos turi mažai bendrų dalykų. Tačiau laikui bègant galimi tokie variantai [1]: 1) viena kultūra isilieja i

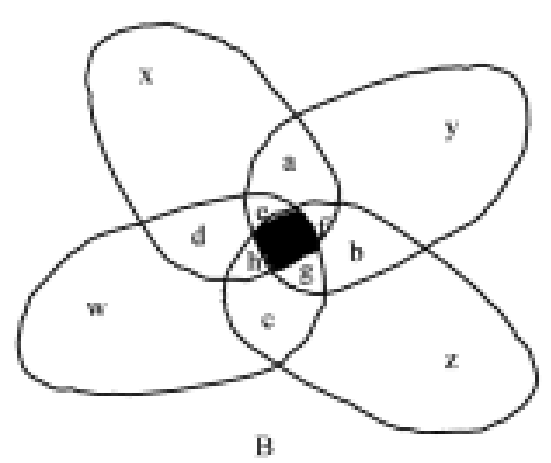

2 pav. Subkultūros organizacijos kultūroje

Fig 2. Subcultures in organizational culture 


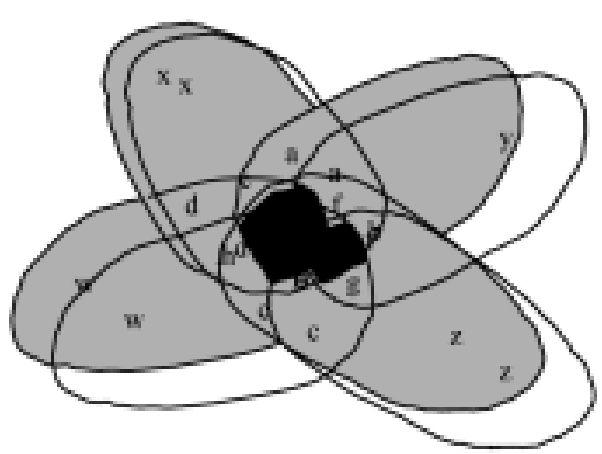

3 pav. Subkultūrų ir kultūros vaizdas įmonèms jungiantis [38]

Fig 3. View of subcultures and culture when enterprises merge [38]

kita, perimdama šios bruožus (tai įvardijama asimiliacija); 2) kultūros susilieja ir suformuoja naujus kultūros bruožus, taigi ir naują kultūrą; 3) jos išlieka kaip atskiros subkultūros (tai įvardijama atsiskyrimu).

Kadangi jungimosi periodu abi įmonès dar nèra suformavusios bendros kultūros, tirti reikètų ne naujo junginio kultūra, o jị sudarančias subkultūras (susijungusių įmonių kultūras). Taigi skirtingų imonių darbuotojų atsakymai i tyrejjo klausimus turètų būti vertinami atskirai, o po to lyginami.

Imoniu jungimosi periodu analizuodami jas kaip vieną jungini galime gauti netikslų rezultata, ypač tuomet, kai vienos imonès darbuotoju yra gerokai daugiau, ir ju atsakymai bus lemiami. Gali pasirodyti, kad organizaci- jos nariai kultūrą ìvertino teigiamai, kadangi bus išvestas aritmetinis atsakymų vidurkis (pagal Denison [15] modeli). Tačiau šis įvertinimas gali klaidinti. Jeigu imones analizuosime atskirai, vaizdas pasidarys aiškesnis, nes matysime, kurioje subkultūroje yra problemų, susijusių su veiklos efektyvumu/sèkme. Iš kiekvienos subkultūros (organizacijos) svarbu atrinkti tiek respondentų, kad būtų galima daryti išvadas apie nagrinėjamas subkultūras. Toliau pateikiamas sąlyginis pavyzdys (žr. 4 pav.).

Tai sumodeliuota situacija. Pateiktas grafinis vaizdas leidžia matyti, koks skirtumas pateikiant susijungusių įmonių duomenis kaip atskirų organizacijų ir kaip vientiso junginio. Hofstede ir kt. [39], tyrę nesusijungusių imonių kultūras, taip pat pastebejjo, kad skiriasi ne tik grupių rezultatai, bet ir rezultatai, kai išvedamas vidurkis iš visų organizacijos narių atsakymų ir kai išvedamas vidurkis iš grupių atsakymų. Taigi subkultūras išskirti, tiriant susijungusias organizacijas, yra naudinga. Be to, naudingas ir pats grafinis vaizdas, kadangi jis tyrèjams ar organizacijų vadovams yra aiškesnis nei skaičiavimai.

Paveikslo apačioje pateikiami sąlyginiai duomenys, o grafikai rodo tų duomenų vaizdavimo galimybes. Kiekviena kriterijų (kultūros aspekta) galima ịvertinti nuo 1 iki 5 balu. , ,5“- aukščiausias ivvertinimas, rodantis, kad kriterijus nagrinejjamoje imonèje yra labai reikšmingas. Kartais per didelis koncentravimasis i tam tikrus dalykus įmonei gali būti nenaudingas [15], todèl interpretuojant duomenis reikia ị tai atsižvelgti. Skaičiavimai atlikti ir grafikai braižyti naudojant „Excel“" programą.

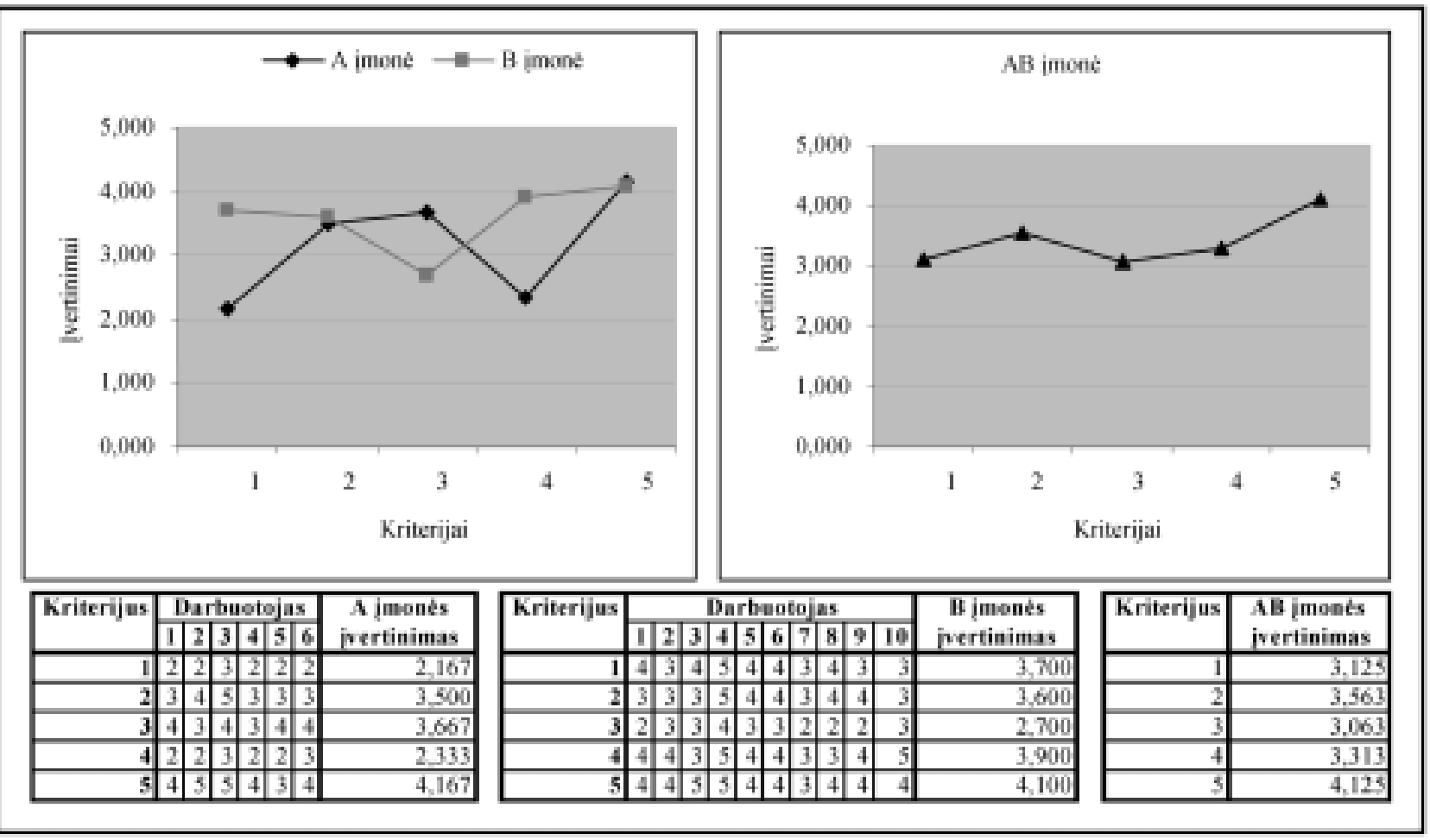

4 pav. Salyginis subkultūrų atskyrimo kultūros analizeje pavyzdys

Fig 4. Conditional example of separation of subcultures in culture analysis 
Lentelès rodo, kaip kiekvieną kriterijų ivertino darbuotojai, ir kokie yra vidutiniai kiekvienos įmonès įvertinimai. Jie skaičiuojami sudejus kiekvieno darbuotojo įvertinimą ir sumą padalijus iš kriterijus vertinusių darbuotojų skaičiaus. Analizuodami grafikus pamatysime, kad naujos organizacijos $(\mathrm{AB})$ įvertinimų vaizdas (visų darbuotojų įvertinimų vidurkis) skiriasi nuo to, kuri gauname susijungusių i̇monių ỉvertinimus pateikę skyrium. Pavyzdžiui, A įmonès darbuotojai pirmaji kriteriju ivertino nepalankiai, o B imonès darbuotojai tą pati kriterijų ivertino teigiamai. Bendras vaizdas rodo, kad šis kriterijus užima vidutinę poziciją. Taigi nematysime, kur glūdi problemos, jeigu nežinosime, iš kurios subkultūros yra respondentas. Atskirti subkultūras svarbu net ir tuomet, kai kiekvienos iš susijungusių imonių darbuotojų skaičius yra panašus. Tuomet darbuotojus veiks ta kultūra, kuri bus stipresnè ir patrauklesnè [1]. Be to, panagrinëję kiekvieną subkultūrą, pamatysime, kuria kryptimi juda susijungusios įmonès, kurie kultūros aspektai atitolę, o kurie bendri.

Prieš susijungimą imones nagrinėsime atskirai, nes jos dar nebuvo susijungusios. Jau buvo aptarta, kad tiriant jungimosi periodą imones taip pat verta analizuoti kaip atskirus vienetus. Tyrejją domina ne tik jungimosi periodas, bet ir periodas po susijungimo. Paanalizavę šio laikotarpio veiklos rezultatus, pamatysime, ar susijungimas pateisino organizacijų lūkesčius. Kyla klausimas - ar šiuo periodu išskirti subkultūras, ar atskirti darbuotojų, priklausiusių skirtingoms organizacijoms, atsakymus. Kadangi po imonių susijungimo gali būti praejjęs nemažas laiko tarpas, tikètina, kad jos visiškai susiliejo ir susiformavo nauja organizacijos kultūra (nebeliko senujų kultūrų bruožų). Tačiau gali būti ir taip, kad organizacijoje iš skirtingų įmonių susiformavo ryškios skirtingos subkultūros, kurias sieja tik kai kurie bendri dalykai. Vadinasi, noredami pamatyti, kokia yra susijungusių organizacijų kultūros būklè, jas reikètų analizuoti kaip atskirus vienetus. Tuomet matysime, ar organizacijos visiškai susiliejo, ar ne, ar jos netrukdo viena kitai ir kaip tai veikia imonès rezultatus. Be to, jeigu neišskirtume subkultūrų, turètume nevienodus vienetus ir jų negalètume palyginti skirtingais laikotarpiais (žr. 4 skyrių). Vadinasi, susijungimo (pokyčio) negalètume įvertinti tiksliau. Toks tyrimas bus naujas, kadangi susijungusias imones mokslininkai tiria kaip vientisa jungini, t. y. vienos imonès darbuotojų nuomones analizuoja kartu su kitos įmonès darbuotojų nuomonėmis, o ne atskirai.

\section{Tyrimo metodų integracija}

Literatūros analizè parodè, kad autoriai, taikantys kiekybinius tyrimo metodus, tiria nesusijungusias organizacijas, o autoriai, taikantys kokybinius tyrimo metodus, dažniausiai tiria vieną (susijungimo) perioda, kai kurie autoriai įvertina ir įmonių praeiti. Tačiau pagal kokybinius metodus ne visuomet galime daryti išvadas apie susijungusių imonių kultūrų poveiki sèkmei, nes vadovaudamiesi šiais metodais mokslininkai ištiria nedaug susijungimo atvejų. Todèl galima teigti, kad susijugusių imonių kultūros poveikis sèkmei dar nèra išsamiai įvertintas dèl šiam poveikiui nustatyti pasirinktų metodų ir dẻl bendrų kultūros aspektų bei veiklos rodiklių trūkumo. Be to, netinkamai analizuojamas susijungimas - susijungusių organizacijų kaip vientiso junginio analizè, taip pat neduos tikslaus atsakymo apie susijungimo sėkmės/nesėkmių priežastis. Norint

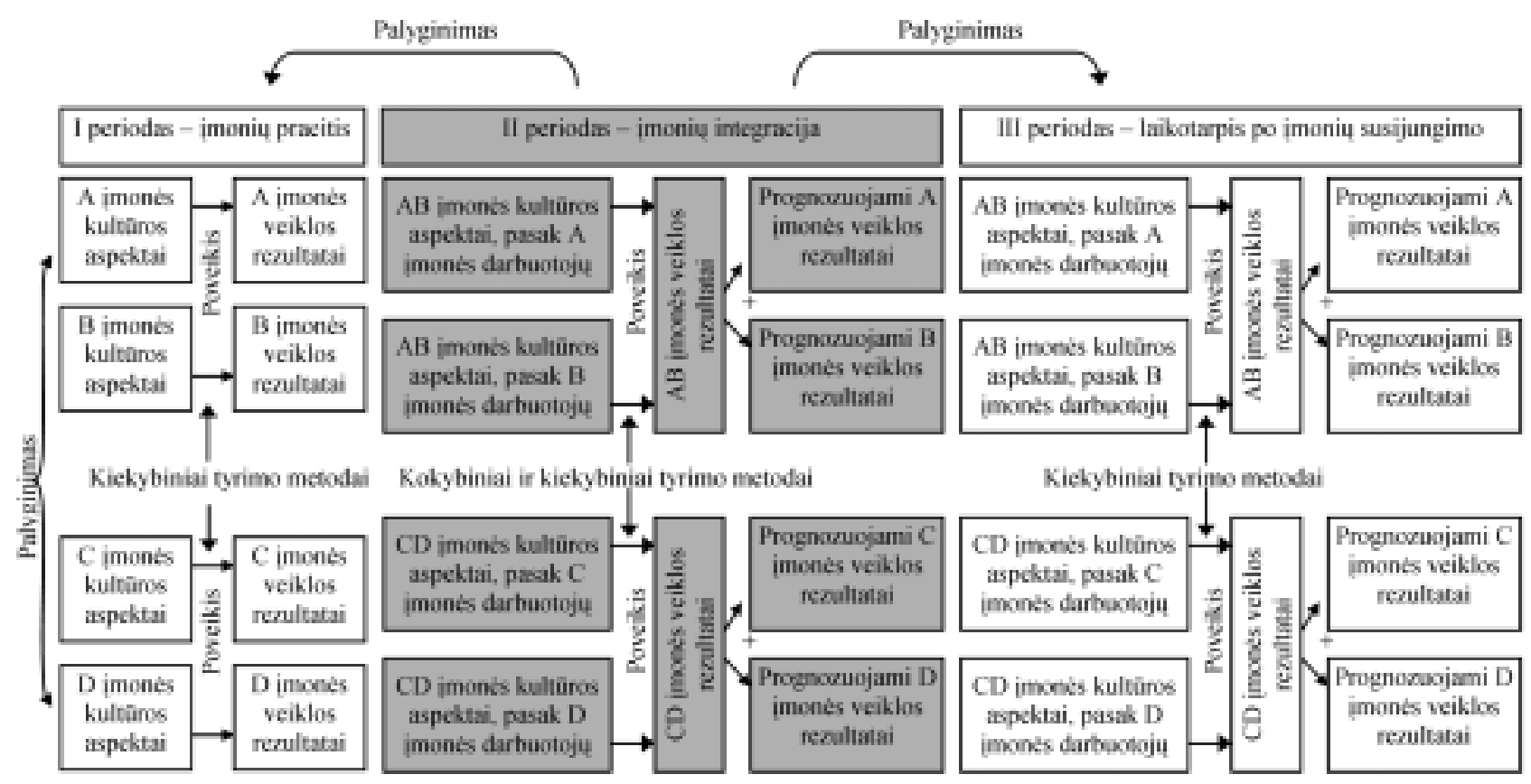

5 pav. Tyrimo metodų integracija

Fig 5. Integration of research methods 
nustatyti kultūros/jos apektų poveikị veiklos rezultatams/ sėkmei, siūloma integruoti keletą kultūros tyrimo metodų. Taigi tyrimas turètų apimtis šiuos etapus:

1. Reikšmingų kultūros aspektų ir veiklos rezultatų rodiklių išskyrimą (teorinis lygmuo).

2. Tyrimo periodų išskyrimą, norint ịvertinti pokyti, $t$. y. norint įvertinti, kaip keičiasi kultūros aspektai ir kaip keičiasi jų poveikis sèkmei.

3. Susijungusių organizacijų analizę, immones traktuojant kaip subkultūras, o ne kaip vientisa jungini.

4. Kokybinių ir kiekybinių metodų derinimą.

Visus šiuos aspektus siūloma apjungti ì visumą (žr. 5 pav.). Susijungusios organizacijos analizuojamos kaip atskiri vienetai. Tokia pati analizès eiga išlieka visais tyrimo periodais, tik įmonių integracijos periodu siūloma greta kiekybinių tyrimo metodų taikyti ir kokybinius, nes šis periodas tyrèjui yra svarbiausias.

Veiklos rezultatai, kaip jau buvo minèta, gali būti tiek finansiniai, tiek ne finansiniai rodikliai. Ieškant ryšio tarp kultūros ir i̇monès sèkmès, naudinga naudoti abi rodiklių grupes (žr. 3 skyriu). Dèl vietos stokos 5 pav. pateiktas tik supaprastintas vaizdas. Be to, kultūrą nusako daugybė jos aspektu, paveiksle jie taip pat neparodyti. Taigi kiekybiniais ir kokybiniais metodais turètų būti tiriamas ryšys tarp kiekvieno kultūros aspekto ir veiklos rodiklio. Abu tyrimo metodai taikytini tik tiriant susijungimo perioda, kadangi mus domina būtent susijungimo sėkmès ir nesėkmių priežastys. Kitų periodų analizė leis minètas priežastis išryškinti, kadangi tik palyginę periodus, matysime kaip skiriasi kultūros aspektų poveikis įmonès sèkmei. Šiame darbe kiekybinès analizès esmè ta, kad îvertinami keli vienos organizacijos laikotarpiai, ivertinamos kelios organizacijos tam tikru vienu periodu ir ịvertinama kelių organizcijų keli laikotarpiai.

Kokybinès analizès esmè ta, kad įvertinama konkrečios organizacijos konkreti situacija. Kokybinė analizè yra detalus situacijos įmoneje ištyrimas, todèl neịmanoma ištirti daug atvejų. Tarp ištirtų atvejų turètų būti ieškoma dèsningumų ir jie lyginami keliose organizacijose. Tokia analizè papildo kiekybinę analizę, t. y. tai, ko nebuvo i̇manoma nustatyti kiekybinio tyrimo metu, atskleidžia kokybinis tyrimas.

\section{Išvados}

Analizuojant susijungusių organizacijų kultūras ir jų poveiki imonès sèkmei, svarbu naudoti tokią tyrimo metodika, kuri ši poveiki leistų ivvertinti kuo tiksliau. Literatūroje šis poveikis dar nėra išsamiai išanalizuotas. Pagrindinès analizės problemos - autoriai neišskiria laikotarpių arba pasirenka netinkamą tyrimo būdą ir jų nederina bei imonių jungini nagrinejja kaip vieneta.

Autore siūlo analizuojant ši poveiki išskirti tris laikotarpius: prieš susijungima, jungimosi metu ir po jo. Palyginus skirtingus periodus, išryškès susijungimo sèkmès ar nesėkmių priežastys. Laikotarpių išskyrimas gali būti naudingas tiriant ne tik susijungimus, bet ir kitus įmonių pokyčius. Tuomet antrasis periodas būtų ivardijamas pokyčių periodu.

Kokybiniai tyrimo metodai dažniausiai atskleidžia tik tiriamoms įmonèms būdingus aspektus, o taikant kiekybinius metodus jungimosi situacija dažniausiai ištiriama tik paviršutiniškai. Todẻl abu tyrimo metodus verta derinti.

Ne visi mokslininkai turi galimybę stebėti imonių susijungima. Todèl susijungusias organizacijas jie tiria pagal praeities faktus. Kadangi susijungusių imonių darbuotojai dažniausiai dirba jau ,,po vienu stogu“, tyrèjai susijungusias organizacijas analizuoja kaip vientisa jungini. Autorès pateiktas sąlyginis pavyzdys parodè, kad jeigu susijungusias įmones tirsime kaip vieną organizaciją, nematysime, kur glūdi problemos. Todèl įmones vertètų traktuoti kaip subkultūras ir jas analizuoti atskirai. Tai leis pamatyti, kuri subkultūra ir koki poveiki daro naujos įmonès sėkmei, ar kultūrų aspektai labai atitolę, kurie aspektai bendri ir kuria kryptimi juda susijungusios organizacijos.

Tiriant susijungusias įmones, periodų bei subkultūrų išskyrima, kokybinių ir kiekybinių metodų derinimą reikia integruoti. Integruota tyrimo metodika duos tikslesnių rezultatų nei paskirų metodų taikymas.

Pateiktus tyrimo metodikos metmenis - tyrimo suskirstymą periodais, tyrimo metodų derinimą ir subkultūrų išskyrima - galima pritaikyti ir kitoms susijungimo problemoms tirti. Pavyzdžiui, taikant panašią metodika galima analizuoti susijungusių imonių finansus, personalą ir pan., t. y. pasiūlytais tyrimo metodikos metmenimis gali pasinaudoti ir kitų mokslo sričių tyrèjai, analizuojantys susijungusias organizacijas.

\section{Literatūra}

1. Nahavandi, A.; Malekzadeh, A. R. Organizational Culture in the Management of Mergers. Westport, Connecticut, London: Quorum Books, 1993. 175 p.

2. Cartwright, S.; Cooper, C. L. The Impact of Mergers and Acquisitions on People at Work: Existing Research and Issues. British Journal of Management, Vol 1, 1990, p. 65-76.

3. Cartwright, S.; Cooper, C. L. Organizational marriage: "hard" versus "soft" issues? Personnel Review, Vol 24 Issue 3, Jun 1995 , p. 32-43.

4. Roger, M. How culture Affects Mergers and Acquisitions. Industrial Management, Vol 42, Issue 5, Sep/Oct 2000, p. 22-27.

5. Shearer, C. S.; Hames, D. S.; Runge, J. B. How CEOs influence organizational culture following acquisitions. The Leadership\&Organizational Development Journal, Vol 22, No 3, 2001, p. 105-113.

6. Schein, E. H. Organizational culture and leadership. Second Edition. San Francisco: Jossey-Bass Publishers. 1992. 418 p.

7. Aldag, R.J.; Stearns, T.M. Management. Cincinnati West Chicago: South-Western Publishing Co., 1987. 890 p.

8. Oh, E. The value of corporate culture. Malaysian Business. Kuala Lumpur, Nov. 1, 2000, p. 50-51.

9. Cartwrigh, S. Cooper, C. L. The role of culture compatibility 
in successful organizational marriage. Academy of Management Executive, Vol 7 Issue 2, May 1993, p. 57-71.

10. Carleton, J. R.; Lineberry, C. S. Achieving Post-Merger Success: A Stakeholder's Guide to Cultural Due Diligence, Assessment, and Integration. New York: John Wiley\&Sons, Inc., 2004. 213 p.

11. Moorhead, G.; Griffin, R. W. Organizational behavior. Second edition. Boston: Houghton Mifflin Company. 1989. $628 \mathrm{p}$.

12. Tuulik, K.; Alas, R. The impact of the values of top managers upon their subordinates values. Journal of Business Economics and Management / North-German Academy of Informatology (Stralsund), 2003, Vol IV, No 2, p. 105-115

13. Vargic, B.; Luptakova, S. Managerial style and its managerial implications for organizations in the Slovak Republic. Journal of Business Economics and Management / North-German Academy of Informatology (Stralsund), 2003, Vol IV, No 1, p. 36-45

14. Poole, M. S.; Van de Ven, A. H. Using Paradox to build Management and Organization Theories. The Academy of Management Review, Vol 14, No 4, Oct 1989, p. 562-578.

15. Denison, D. R. Organizational Culture: Can it be a Key Lever for Driving Organizational Change? In: The Handbook of Organizational Culture. Edited by S. Cartwright and C. Cooper. London: John Wiley \& Sons, 2000, p. 1-25.

16. Cartwright, S.; Cooper, C. L. Of Mergers, Marriage and Divorce. Journal of Managerial Psychology, Vol 8, No 6, 1993, p. 7-10.

17. Schneider, W. E. Why good management ideas fail: the neglected power of organizational culture. Strategy \& Leadership, Chicago, Vol 28, Issue 1, Jan/Feb 2000, p. 24-29

18. Horwitz, F. M.; Andersen, K.; Bezuidenhout, A.; Cohen, S.; Kirsten, F.; Mosoeunyane, K.; Smith, N.; Thole, K.; van Heerden, A. Due diligence neglected: managing human resourses and organizational culture in mergers and acquisitions. South African Journal of Business Management, Vol 33, Issue 1, Mar 2002, p. 1-10.

19. Stoner, J. A. F.; Freeman, R. E.; Gilbert, D. R. Management (Vadyba). Kaunas: Poligrafija ir informatika, 1999. 618 p. (in Lithuanian).

20. Flamholtz, E. Corporate culture and the bottom line. European Management Journal, Vol 19, Issue 3, June 2001, p. 268275.

21. Harris', L. C.; and Metallinos, G. The fact and fantasy of organizational culture management: a case study of Greek food retailing. Journal of Retailing and Consumer Services, Vol 9, Issue 4, July 2002, p. 201-213.

22. Barvydienè, V.; Kasiulis, J. Psychology of management (Vadovavimo psichologija). Kaunas: Technologija. 1998. 163 p. (in Lithuanian).

23. Ivancevich, J. M.; Matteson, M. I. Organizational behavior and management. Second Edition. Homewood, Boston: IRWIN. 1990. 676 p.

24. Brannen, M. Y.; Salk, J. E. Partnering across borders: Negotiating organizational culture in a German-Japanese joint venture. Human Relations. Vol 53, Issue 4, Apr. 2000, p. 451487.

Vida VAITKŪNAITĖ. Doctoral student of Department of Enterprise Economics and Business Management, Vilnius Gediminas Technical University. Research interests: organizational culture, its impact on enterprise success, merged organizations.
25. Sparrow, P. R. Developing Diagnostics for High Performance Organization Cultures. In: The International Handbook of Organizational Culture and Climate. Chichester, New York, Weinheim, Brisbane, Singapore, Toronto: JohnWilley\&Sons, LTD, 2001, p. 85-103

26. Veiga, J.; Lubatkin, M.; Calori, R.; Very, P. Measuring organizational culture clashes: A two-nation post-hoc analysis of a cultural compatibility index. Human Relations. New York, Vol 53, Issue 4, Apr 2000, p. 539-557.

27. Spivak, V. A. Organizational culture: theory and practice (Корпоративная культура: теория и практика). Sankt-Peterburg: Piter, 2001. 332 p. (in Russian).

28. Lemon, M.; Sahota, P. S. Organizational culture as a knowledge repository for increased innovative capacity. Technovation. In:

Press, Corrected Proof, Available online 20 January 2003. http:// www.sciencedirect.com/

29. Cabrera, I.; Cabrera, E. F.; Barajas, S. The key role of organizational culture in a multi-system view of technology-driven change. International Journal of Information Management, Vol 21, Issue 3, June 2001, p. 245-261.

30. Ouchi, W. G. Theory Z. Reading, Mass.: Addison-Wesley, 1981. 283p.

31. Fey, C. F.; Denison, D. R. Organizational Culture and Effectiveness: Can American Theory Be Applied in Russia? Organization Science: A Journal of the Institute of Management Sciences, Nov/Dec, Vol 14, 2003, p. 686-706.

32. Denison, D. R.; Mishra, A. K. Toward a Theory of Organizational Culture and Effectiveness. Organization Science, Vol 6, No 2, March-April 1995, p. 204-223.

33. Bjerke, B.; Elgar, E. Business Leadership and Culture: National Management Styles in the Global Economy. Cheltenham: Edward Elgar, 1999. 287 p.

34. Diamond, M. A. The Unconscious Life of Organizations: Interpreting Organizational Identity. Westport, Connecticut London: Quorum Books, 1993. 256 p.

35. Child, J.; Faulkner, D. Strategies of Cooperation: managing Alliances, Networks, and Joint Ventures. Oxford: Oxford University, 1998. $378 \mathrm{p}$.

36. Fairlholm, G. W. Leadership and the Culture of Trust. Westport, Connecticut London: Praeger Publishers, 1994. 246 p.

37. Karabanow, J. The organizational Culture of a Street Kid Agency: Understanding Employee Reactions to Pressures to Feel. In: Emotions in the Workplace: Research, Theory, and Practice. Edited by N. M. Ashkanasy, C. E. J. Härtel, W. J. Zerbe. Westport, Connecticut London: Quorum Books, 2000, p. 165-176.

38. Vaitkūnaitè, V. Analysis of impact of organizational culture and subcultures on enterprise success. In: 7-th conference of young scientists: ,Lithuania without science - Lithuania without future“ (7-oji Lietuvos jaunujų mokslininkų konferencija „Lietuva be mokslo - Lietuva be ateities“). Vilnius: Technika, 2004, p. 80-86 (in Lithuanian).

39. Hofstede, G.; Neuijen, B.; Ohayv, D. D.; Sanders, G. Measuring organizational cultures: A qualitative and quantitative study across twenty cases. Administrative Science Quarterly, Vol 35 Issue 2, Jun. 1990, p. 286-316. 